\section{Supporting Sustainability for a Decent Work and Economic Growth in Ghana}

\author{
Julia Bello-Bravo $^{1}$ and Anne Namatsi Lutomia ${ }^{2}$ \\ ${ }^{1}$ Department of Food Science and Human \\ Nutrition, Michigan State University, East \\ Lansing, MI, USA \\ ${ }^{2}$ Department of Entomology, Michigan State \\ University, East Lansing, MI, USA
}

\section{Definitions}

Goal 8 of the Sustainable Development Goals (SDGs) aims to promote decent, inclusive, and sustainable economic growth and full/productive employment for all (United Nations 2015). According to the United Nations (UN), sustainable economic growth is foregrounded where benefits exist for men and women equally and inequalities are reduced while sustaining the environment. Further, inclusive economic growth requires decent work - work that is secure, safe, with fair wages, and equally accessible to men and women (United Nations 2015).

\section{Introduction}

The Sustainable Development Goals or Global Goals based on the 2030 Agenda for Sustainable
Development were adopted by more than 150 world leaders on 25 September 2015. Seventeen goals were identified with the mission of eradicating poverty and hunger in the world, protecting the environment, and fostering peace and inclusive societies, among other aims. The SDG document comprises 17 goals, 169 targets, and 230 indicators. The precedent of the SDGs was the Millennium Development Goals (MDGs), launched in 2001, with a global agenda to reduce poverty by 2015 (UNDP 2015). All the SDGs are interconnected to end poverty by 2030 . In particular, action plans to accomplish poverty reduction by national governments need to understand, practice, and recognize the linkages between multiple development goals and work in areas where weakness and disparities are still visible. Some of the gaps in some African countries - including gender and socioeconomic inequality, illiteracy rate, and the urban and rural divide - require measures, strategies, and decisions from each government that incorporate decisions as part of their national planning, processes, and policies for poverty reduction.

Notably, providing flexibility to national governments for working toward 2030 Agenda goals remains challenging. According to Gornitzka and Pipa (2019), two main approaches address this challenge. First, national governments can adopt a whole-of-government approach, which includes setting national priorities based on their own circumstances while investing internationally to 
drive global progress. Second, they can consider a whole-of-society approach by providing leadership for bringing together various stakeholders. These approaches are not, of course, mutually exclusive; Ghana presents on such case of "mixed" approaches (Government of Ghana 2019).

Besides the 2030 Agenda, African countries have also committed to implementing the African Union Agenda 2063. In 2013, African Union Agenda 2063 was launched by African heads of state and expressed a rededication to the African Union's founding vision of "an integrated, prosperous and peaceful Africa, driven by its own citizens, representing a dynamic force in the international arena" (African Union 2020). This agenda is a vision and action plan intended to drive Africa's change, development, and transformation for the next 50 years. The 2030 Agenda for Sustainable Development considers Agenda 2063 integral in achieving its outcomes (DeGhetto et al. 2016).

Ranked as one of the African countries with the best prospects of achieving various Millennium Development Goals (MDGs) (Arhin 2016), the Government of Ghana (2019) reported that targets such as halving extreme poverty (MDG 1A), achieving universal primary education (MDG 2A), achieving gender parity in primary schools (MDG 3), and halving the proportion of people without access to safe drinking water (MDG 7B) had been attained. Substantial progress was also made in reducing HIV prevalence (MDG 6C) and increasing access to ICT (MDG 8F). Slower progress was achieved toward reducing under-five child mortality (MDG 4), reducing maternal mortality (MDG 5), achieving an equal share of women in wage employment in nonagriculture sectors and women's involvement in governance (MDG 3), and reversal of the loss of environmental resources (MDG 7).

Ghana's success in implementing some of the MDGs is predicated on many factors. Hughes (2005) wrote that the postcolonial history of Ghana includes times of political upheaval and relative political stability overseen by leaders who enact policies that drive good governance, development, and economic growth. Hughes (2005) also emphasizes that Ghana has a good relationship with donor organizations (such as the Bretton Woods institutions) and the donor community generally because of good management and implementation of projects. The involvement of civil society elements in designing and implementing development policies, as well as the ability to show impact and thus the return on investment from the donor-funded projects, further contributed to the success of the implementation of the MDGs (Hughes 2005).

For implementing the present SDGs, Ghana is building on lessons learned and successes from the MDGs and pursuing partnerships for that implementation. For instance, Ghana is eliciting participation from relevant stakeholders (including public and private sectors and civil society organizations) in the realization of the SDGs to ensure localization and inclusion. The National Development Planning Commission (NDPC) coordinates SDG-related activities, reports on them, and integrates them into developmental plans, like Agenda 2063 (United Nations 2017). The decentralized national development planning system comprises district planning authorities at the district level, regional coordinating councils at a regional level, and sector agencies, ministries, and the NDPC at the national level (United Nations 2017).

This chapter focuses on SDG 8 (Decent work and economic growth) ("Promote sustained, inclusive and sustainable economic growth, full and productive employment and decent work for all") in Ghana and examines pathways that support it (United Nations 2020a). Specifically, the chapter examines how various stakeholders in Ghana collaborate to implement SDG 8 jointly to ensure that it is localized, is inclusive, and leaves no one behind. In the following, we provide a background on SDG 8 in Ghana, its processes of localizing SDG 8 (including its focus on the role of some actors), and a progress analysis (2016-2020) of that localization.

\section{SDG 8: Decent Work and Economic Growth in Ghana}

The 2030 Agenda for sustainable development changes urges governments to take charge of the 
economic, social, and environmental development of their countries; the notion of including this triple bottom line (economics, social, and environmental) represents a new emphasis on developmental strategies over the past, which focused primarily (if not exclusively) on the economic. In Ghana, policymakers have pursued SDG 8 under the mantra, "A Strong Economy for Jobs and Prosperity." Specifically, government policy is informed by the goal of achieving "full and productive employment and decent work for all women and men, including for young people and persons with disabilities, and equal pay for work of equal value" (GMF 2019, p.40).

Ghana has put in place policy actions to increase access to jobs while encouraging innovation, formalization, and diversification of labor. According to GMF (2019):

\footnotetext{
Results from the Ghana 2015 Labor Force Survey revealed that youth with bachelor's degrees had the highest unemployment rate of 38.7 percent, followed by those with senior high school certificates with 24.1 percent. Those with no qualification had the lowest unemployment rate of 5.8 percent. Government's effort at addressing this high graduate unemployment rate led to the creation of the Nation Builders Corps (NABCO) in 2018, under which 100,000 graduates were offered employment under various modules including, Feed Ghana, Heal Ghana, Revenue Ghana, Technology Ghana and Clean Ghana. (p. 40)
}

The report also states that in 2019, ongoing programs were introduced in the 2018 budget to improve growth in the non-oil sectors. These programs include but are not limited to the One-District-One-Factory (1D1F) Program Planting for Food and Jobs (PFJ), the Infrastructure for Poverty Eradication Program (IPEP), and the National Entrepreneurial and Innovation Program (NEIP) among others (GMF 2019).

Table 1 summarizes priority policy initiatives, associated SDGs, and their interlinkages to other SDGs. The implementation of these programs aims at the government's overarching objective to achieve "A Strong Economy For Jobs And Prosperity" (Goal 8).

Relying on the support from the United Nations to attain all of the 17 interlinked SDGs generally involves collaborative partnerships between governments, private sectors, research, academia, and civil society organizations (CSOs) (United Nations 2017). While the UN Sustainable Development Partnership (UNSDP) 2018-2022 sets out the collective support of 24 United Nations agencies working in Ghana (United Nations 2019), additional support and resources for the implementation of the SDGs come through philanthropic activities. Toward this end, the Sustainable Development Goals Philanthropy Platform (SDGPP) works to establish pathways for engaging philanthropy in the national SDG planning and implementation in eight pilot locations, including Ghana (SDGPP 2020).

For SDG 8 specifically, The Sustainable Development Goals (SDGs) in Ghana: Why they matter and How we help (2017) argues that this goal especially matters because Ghana is already comparatively well-positioned to achieve the goal of "sustaining economic growth through increased productivity through technological innovation" (United Nations 2017) and poverty eradication; indeed, past efforts have demonstrated the latter's capacity (Government of Ghana 2019). However, Ghana's high population of under- or unemployed higher educated young people not only remains a barrier to moving into higher levels of development and, thereby, toward wider implementation for SDG 8 nationwide (GMF 2019) but also may threaten social conflict or political instability (United Nations 2017). The Sustainable Development Goals (SDGs) in Ghana: Why they matter and How we help (2017) therefore outlines nine subgoals and their rationales for SDG 8 in Ghana:

- Encourage government commitment and practical measures to improve the enabling environment for business, to make it easier to invest and create more jobs. - As an employer, you can provide decent working conditions: ensure work that is productive and delivers fair income; guarantee workplace safety; participate in social benefit schemes, health insurance, and pensions; invest in training that improves workplace productivity and prospects for personal development; create equal opportunities for women and men; pay your employees their due wages and benefits; mentor young entrepreneurs; encourage creativity and innovation in the workplace. •Enhance industry-school relationship for improved skills training. You can encourage entrepreneurship, increase and promote Technical 
Supporting Sustainability for a Decent Work and Economic Growth in Ghana, Table 1 Interlinkages of SDF8 and Other SDG Goals

\begin{tabular}{l|l|l}
\hline Overarching goal (SDG 8) & Implementation objective & $\begin{array}{l}\text { Linkage to other } \\
\text { SDGs }\end{array}$ \\
\hline $\begin{array}{l}\text { Decent work and economic growth (“A strong economy for } \\
\text { jobs and prosperity”) }\end{array}$ & $\begin{array}{l}\text { Target female participation in new } \\
\text { job initiatives }\end{array}$ & SDG 1 \\
\hline & Planting food and jobs & SDG 2 \\
\hline & Nation builders corps & SDG 8 \\
\hline & One-building-one factory & SDG 9 \\
\hline & Afforestation for climate & SDG 13 \\
\hline & Establish development authorities & SDG 16 \\
\hline
\end{tabular}

Source: Adapted from GMF (2019)

and Vocational Education and Training (TVET), equip TVET schools for quality skills training and improve standards, and especially support girls in TVET. • You can gain additional skills to improve your employability: enroll in skill training, and get a career mentor. -If you are a business owner, register your business, pay your taxes, and demand quality public services in return - in public safety, schools, infrastructure, water and sanitation, parks, and green spaces. - Additionally, ensure that policymakers make youth employment a priority, making the transition from education to a decent job easier by investing in education and training of the highest possible quality that provides youth with skills that match the labor market demands. Ensure employees enjoy social protection, and advocate for more extensive, well-managed social protection programs that promote the public welfare, women's economic empowerment, and decent work for all. $\bullet$ Enforce laws to stop child and forced labor. $\bullet$ Everyone can contribute to creating a decent work environment. You can help your colleagues and report workplace harassment or work-based abuse. (p. 19)

\section{Localizing the SDG 8 in Ghana}

Localizing SDGs involves incorporation, implementation, and monitoring strategies for local development in cities and territories. In other words, it places cities and territories as the center stage of activity and aims at empowering collective actions by local actors. Localization of SDGs includes their translation into local agendas leading to the creation of mechanisms, tools, innovations, platforms, and processes of sustainable development actions tailored to subnational contexts (UNDP 2015). Localization relates to both the ways SDGs function as a framework for local development and how local and regional governments (LRGs) rely on bottom-up approaches to contribute to the achievement of the SDGs at a national level.

The process of localization of SDGs in Ghana has involved a tripartite strategy of alignment, adaptation, and adoption. Each of these involves a decision-making and assessment process on how to merge SDG development plan goals and monitoring within a Ghanaian context:

- Alignment: Operationalized at a national level, the National Development Planning Commission (NDPC) would align national development policy frameworks with SDGs and other planning organizations, including ministries, departments, and agencies (MDAs) and metropolitan, municipality, and district assemblies (MMDAs). Specifically, this involves aligning Ghanaian development goals, such as the Ghana Shared Growth and Development Agenda (GSGDA II) and the long-term National Development Plan, which will be implemented over the next 40 years starting from 2018, with SDG goals.

- Adaptation: This involves NDPC-made adjustments to SDG targets to take account of national contexts in Ghana with respect to the national development plan.

- Adoption: This involves NDPC-determined assessments of SDGs already suitable for, and 
not requiring modification to fit, the national development plan.

Although the "theme" of culture remains somewhat masked in this tripartite strategy, it deeply informs the localization process. For example, while SDG 5 specifically addresses gender inequality, the line item above from SDG 8, "create equal opportunities for women and men" (United Nations 2017, p. 19) restates, in a work context, the SDG 5 goal of eliminating gendered inequalities. For the three strategies above, however, the decision-making processes of localization involve determining how to do this feasibly in a Ghanaian context, i.e., by adoption outright of the SDG's framing of gender equality, adaptation of that framework to or through existing gender inequalities in Ghana, or cultural-engineering approaches that align MDA and MMDA policies with national policies to normalize SDG frameworks culturally.

The issue of gender equality is an apt and difficult example of the challenges faced by localization given how the discourse between (a previously colonizing) "West" and (a previously colonized) "Africa" makes fraught any discussion, much less imposition, of "culture." That is, it becomes difficult to separate whether "Western" framings of gender equality and inequality actually offer a culturally competent view or critique of male-female relations in "Africa" or simply restate - as old wine in new skins - the cultural inferiorization that colonialism imposed (Okolie 2003). The emphasis of the issue here is not, of course, any internal validities of "Western" or "African" discourse on cultural gender relations (even as these remain open questions) but, rather, issues about the interactive qualities of the power dynamics in play when world stakeholders use soft rather than coercive power to elicit alignment or commitment by less empowered stakeholders to those world stakeholders' frameworks (Lutomia 2019; Madela 2020; Nye 2004). At a minimum, African stakeholders who are charged with and committed to implementing SDG goals realize this often painful and challenging situation; consequently, a strategy such as alignment, adaptation, and adoption emerges as a way to negotiate and account for the challenges that arise from those circumstances.

\section{Actors in Localizing SDG 8 in Ghana}

A key global focus of implementing SDG goals involves securing resources to finance those goals, which links SDG 8 to SDG 17: "Strengthen the means of implementation and revitalize the global partnership for sustainable development" (United Nations 2020b). Localizing thus involves actors of varying echelons across the society, including local authorities, nongovernmental stakeholders, foundations, businesses, governments, civil society organizations, private sector actors, traditional leaders, religious organizations, academia, and the broader public generally. While the good partnerships of SDG 17 leverage resources and knowledge to increase impacts, sustainability, and value in general, similar decision-making to align, adapt, or adopt policies for a good cultural fit in Ghana shapes where those partnerships form.

Some of these SDG 17 partnerships include civil society organizations, philanthropies, and Nongovernmental organizations (NGOs). In Ghana, specifically, the government has worked with numerous partners to localize common interests for realizing SDG goals. One of these is the SDG Philanthropy Platform (SDGPP), which helps drive localization efforts for Ghana's SDG goals by providing finance and policy recommendations toward better SDG outcomes. An SDG Implementation Coordinating Committee advises and shapes the alignment of Ghanaian SDG with the national development framework (SDGPP 2020). Similarly, while NGOs are frequent SDG 17 partners, NGOs advancing Ghanaian SDGs are particularly affected by three main factors: (1) uncertainties around income generation and funding sources, (2) changing operational capacities and competencies, and (3) shifts in NGO identities or missions themselves (Arhin et al. 2015; Hughes 2005). These sorts of organizational partnerships aim to be as inclusive as 
possible and do, to some extent, serve as intermediates or throughputs between top-down (national) and bottom-up (grassroots) efforts.

\section{Private Sector}

Private sector SDG 8 collaborative partnerships strive to bring synergies toward common goals. In Ghana, as in many other African countries, the private sector ensures that the trade of goods and transfer of technology benefit the country and its citizens. Supporting and facilitating investments of new business by the government ensures the social benefit of the country. Ultimately, the private sector can enhance and bridge the financing gap necessary to attract other key partners, such as international donors.

The president of Ghana, Nana Akufo-Addo, has emphasized the importance of the Ghanaian private sector for achieving SDG 8 (and the SDGs generally). Locating the private sector as the primary promoters of social and economic transformation, this resonates with Ghanaians for whom the private sector creates and brings opportunities for the society (Kumi et al. 2019). Nonetheless, while the private sector in Ghana can bring development opportunities for people in rural and urban areas, businesses will have to focus on sustainable models while still pursuing profitability (Kumi et al. 2019; Neto and Riva 2015), i.e., a business model that includes economics, the environment, and social impacts in its calculations of profit. Similarly, the government needs to incorporate sustainable development indicators into its strategies to attract investments from the private sector into the country (Kumi et al. 2019). The OECD (2015) similarly maintains that the principles of good business that the private sector should follow include obeying the law, respecting human rights and labor regulations of the country, avoiding and working against corruption, paying taxes, and being transparent and accountable.

Parts of the Ghanaian private sector have taken a proactive approach to follow the SDGs. Corporate social responsibility (CSR), for example, is a concept much associated with the SDGs for mining and telecommunication companies operating in Ghana (Amoako 2016; Azina-Nartey 2018; Yeboah 2011). The MTN Ghana Foundation is one of the leaders and most studied private sector actors with respect to SDG fulfillment and CSR in Ghana (APA-Accra 2020; Celik et al. 2019; Djabanor 2019; Okolo 2019).

One of the challenges for attaining SDG 8 is limited coordination between the private sector actors and adequate incorporation of participation by all relevant actors in the community and longterm (sustainable) commitments to projects (Azina-Nartey 2018; Djabanor 2019). While CSR can respond to local needs by engaging communities, this should include participatory decision-making about project designs to draw on the strength, agency, and voices of project recipients, but especially underrepresented and marginalized.

\section{Academia}

Academia brings a more recent dimension to the implementation of SDG 8. As a potential career choice, providing students the knowledge and skills to be global citizens means teaching them sustainable values for pursuing an inclusive society (UNESCO 2017). While one mandate of higher education is to prepare the next generation of students in learning, research, and leadership skills, it is important to provide curriculum - and to design courses - around sustainability issues like poverty eradication, food security, global nutrition, labor rights and regulations, entrepreneurship, formal and informal business, and how the values reflected in the SDGs address the challenges these issues raise. According to El-Jardali et al. (2018), universities can play a unique role in accelerating actions on SDGs:

Universities are uniquely placed to lead the crosssectoral implementation of the SDGs, providing an invaluable source of expertise in research and education on all sectors of the SDGs, in addition to being widely considered as neutral and influential players. While the focus of this commentary is on the role of universities, it is acknowledged that think tanks and other institutions involved in the production and communication of knowledge also have an important role in advancing the SDG agenda. (p. 1) 
Moreover, and building on academia as an educative force and career (UNESCO 2017), academia in its professional sense also has a responsibility not simply to promote the SDGs but to empirically research the effectiveness of strategies for fulfilling them (what works, what has not) and identifying improvements or patches on existing frameworks, especially where unequal power dynamics between stakeholders may distort SDG implementations (Lutomia 2019; Madela 2020). In Ghana, $62.8 \%$ of unemployed youth had high school or higher degrees, compared to $5.8 \%$ unemployed who had less than a high school education. While the reasons for this situation are generally well understood (GMF 2019), insofar as education is held out as the key to success, as professional academics, we have a particular responsibility to these youth who have taken up their part of the educational mantle to identify workable, feasible solutions to ensure that that youths' efforts do not go wasted or, worse yet, turn reactionary (United Nations 2017). In this respect, Afful et al. (2019) on Ghana are very much on point.

\section{The Progress in Localizing SDG 8 in Ghana}

According to the SDGPP (2020), progress toward SDG 8 in Ghana includes (1) the country moving in 2010 from lower- to middle-income status (primarily due to high GDP growth in the commercial oil sector); (2) an increased proportion of people in productive employment; (3) an increasing number of new job-market entrants, particularly the youth, contributing to a high employment-to-population ratio (75.6\%); and (4) improved wages for many groups of workers due to shifts from low-paying jobs to betterpaying jobs.

This process is not without challenges, which include:

1. Youth unemployment.

2. That sources of growth tend to be biased in favor of extractive and capital-intensive sectors (which have less direct poverty reduction effects).
3. Little growth in the agriculture sector (primarily due to a lack of modernization measures).

4. Unemployment is uneven, with the working poverty rate remaining high in three northern regions.

5. Low education levels in the workforce restrict access to highly skilled and better-remunerated jobs (SDGPP 2020).

\section{Conclusion}

This chapter examined the gains and challenges, actors, and processes involved in the localization of SDG 8 in Ghana. Nonetheless, in many respects it remains unclear in what way many of the cited measures of localization - especially, for example, economic ones in SDGPP (2020) move substantially beyond the economic only to embrace the sustainable; that is, understanding that sustainable development "generally refers to achieving a balance among the environmental, economic, and social pillars of sustainability" (Afful et al. 2019, p. 1), it often remains unclear where the environmental and social gains are being explicitly tracked or measured in these trends. While the deepening ethos of corporate social responsibility in Ghana certainly emphasizes the social, Afful et al. (2019) can still observe, speaking to sustainable development in Ghana specifically, "the meaning and associated objectives of the social pillar remain vague" (p. 1). Consequently, their paper advocates for a thoroughgoing understanding and implementation of all three pillars of sustainability - work that is particularly in the domain of academia.

Thus, while sustainable development requires us to ask (all but rhetorically only) if impressive growth in an oil sector is environmentally sustainable, still more "elusive" (Afful et al. 2019, p. 1) would be the question whether an educational pedagogy to transform Ghanaian people into global citizens (UNESCO 2015) is socially sustainable. Whether the answer is yes or no - and arguments on both sides exist (Bhargava 2006; Desai 2017; Nzongola-Ntalaja 2004; Sanya 2017; UNESCO 2015) - to take sustainable development seriously requires not only asking 
such a question but also understanding what the social pillar of sustainability could locally refer to, both around the world and in locales, like Ghana, specifically (Afful et al. 2019).

The purpose of this chapter was to provide a synthesis of Ghana's efforts to localize SDG 8. While several economic successes around SDG 8 localization have occurred, linking that localization to national, regional, and international (global) SGD goals generally, more effort could be made to include the environmental and the social more clearly in any measures of success. The current threat of COVID-19 highlights this need for a more than economic-only approach insofar as its threats to the Ghanaian social system may also result in setbacks (if not rollbacks) to further implementing SDG (and other SDG goals).

\section{References}

Afful A et al (2019) Level of knowledge of design professionals on the principles of social sustainability in Ghana. Retrieved 27 Apr 2020, from https://tinyurl. com/AffulEtAl

African Union (2020) Agenda 2063: The Africa We Want. Retrieved 27 Apr 2020, from https://au.int/en/agenda 2063/overview

Amoako GK (2016) CSR practices of multinational companies (MNCs) and community needs in Africa: evidence of selected MNCs from Ghana. In: Vertigans $\mathrm{S}$ et al (eds) Corporate social responsibility in subSaharan Africa. Springer, Cham, pp 217-240

APA-Accra (2020) The MTN Ghana Foundation has donated \$909,090 (about GHC5 million) to support the fight against the spread of the coronavirus (Covid-19) in Ghana. Retrieved 27 Apr 2020, from http://apanews.net/mobile/uneInterieure_EN.php?id= 4938674

Arhin A (2016) Advancing post-2015 sustainable development goals in a changing development landscape: challenges of NGOs in Ghana. Dev Pract 26(5):555-568. https://doi.org/10.1080/09614524.201 6.1189513

Arhin A et al (2015) The state of civil society sustainability in Ghana: striving, surviving or thriving (West Africa civil society institute research report). West Africa Civil Society Institute (WACSI), Accra

Azina-Nartey N (2018) Beneficiary response to Corporate Social Responsibility (CSR)-A Case Study of MTN Ghana Foundation. (Ph.D.), University of Ghana, Accra
Bhargava V (2006) Global issues for global citizens: an introduction to key development challenges. World Bank, Washington, DC

Celik A et al (2019) The impact of corporate social responsibility on community development: evidence from Ghana. Glob J Bus Econ Manag 9(3):122-133. https://doi.org/10.18844/gjbem.v9i3.4288

DeGhetto K et al (2016) The African Union's agenda 2063 : aspirations, challenges, and opportunities for management research. Afr J Manag 2(1):93-116. https://doi. org/10.1080/23322373.2015.1127090

Desai K (2017) Girlscape: transnational productions of neoliberal girlhoods. (Ph.D.), Teachers College, New York

Djabanor A (2019) Social Media as a Public Relations Tool: A Study of MTN Ghana and Vodafone Ghana. (Ph.D.), University of Ghana, Accra

El-Jardali F et al (2018) Changing roles of universities in the era of SDGs: rising up to the global challenge through institutionalising partnerships with governments and communities. Health Res Policy Syst (38):16. https://doi.org/10.1186/s12961-018-0318-9

GMF (2019) Ghana's 2019 SDGs budget report, Accra. Ministry of Finance, Government of Ghana

Gornitzka P, Pipa F (2019) A new type of leadership from national governments is essential for success of the SDGs. Retrieved 27 Apr 2020, from https://www. brookings.edu/blog/up-front/2018/04/24/a-new-type-o f-leadership-from-national-governments-is-essential-f or-success-of-the-sdgs/

Government of Ghana (2019) Voluntary National Review (VNR) report on the implementation of the 2030 agenda for sustainable development, Accra. Ministry of Finance, Government of Ghana

Hughes T (2005) Ghana: a donor success story. S Afr J Int Aff 12(2):75-93. https://doi.org/10.1080/1022046050 9556769

Kumi E et al (2019) Private sector participation in advancing the sustainable development goals (SDGs) in Ghana: experiences from the mining and telecommunications sectors. Ext Ind Soc 7(1):181-190. https:// doi.org/10.1016/j.exis.2019.12.008

Lutomia AN (2019) A case study of successes and challenges in a scientific collaboration program based in the United States and Benin. (Ph.D.), University of Illinois Urbana-Champaign, Urbana

Madela LM (2020) Perspectives on South-North institutional collaboration/partnership research in higher education. (Ph.D.), University of Illinois UrbanaChampaign, Urbana

Neto M, Riva M (2015) What role for the private sector in financing the new sustainable development agenda. Retrieved 27 Apr 2020, from https://www.undp.org/ content/undp/en/home/blog/2015/5/7/What-role-for-th e-private-sector-in-financing-the-new-sustainable-dev elopment-agenda-.html

Nye J (2004) Soft power and higher education. Retrieved 6 Apr 2020, from https://tinyurl.com/JNye2004 
Nzongola-Ntalaja G (2004) Citizenship, political violence, and democratization in Africa. Glob Gov 10(4): 403-409

OECD (2015) Development co-operation report 2015: making partnerships effective coalitions for action. OECD Publishing, Paris

Okolie AC (2003) Producing knowledge for sustainable development in Africa: implications for higher education. High Educ 46(2):235-260. https://doi.org/10.102 3/A:1024717729885

Okolo VO (2019) Impact of corporate social responsibility strategies on consumer patronage of telecommunication industry: an MTN experience in Enugu state. Probl Perspect Manag 17(1):216-229. https://doi.org/10.215 11/ppm.17(1).2019.19

Sanya BN (2017) States of discretion: Black migrating bodies and citizenship in the United States. (Ph.D.), University of Illinois at Urbana-Champaign, Champaign

SDGPP (2020) SDGPP in Ghana. Retrieved 27 Apr 2020, from https:/www.sdgphilanthropy.org/

UNDP (2015) Ghana millennium development report. UNDP, Accra

UNESCO (2015) Global citizenship education: topics and learning objectives. UNESCO, Paris
UNESCO. (2017). Education for sustainable development goals: learning objectives. Paris: UNESCO

United Nations (2015) Transforming our world: the 2030 Agenda for Sustainable Development. Retrieved 27 Apr 2020, from https://sustainabledevelopment.un. org/post2015/transformingourworld

United Nations (2017) The Sustainable Development Goals (SDGs) in Ghana: Why they matter \& How we can help. Retrieved 27 Apr 2020, from https://www. undp.org/content/dam/unct/ghana/docs/SDGs/UNCTGH-SDGs-in-Ghana-Avocacy-Messages-2017.pdf

United Nations (2019) Our work on the sustainable development goals in Ghana. Retrieved 27 Apr 2020, from https://ghana.un.org/en/sdgs

United Nations (2020a) SDG 8: decent work and economic growth. Retrieved 27 Apr 2020, from https://unstats. un.org/sdgs/report/2016/goal-08/

United Nations (2020b) SDG 17: Partnerships for the Goals. Retrieved 27 Apr 2020, from https://unstats.un. org/sdgs/report/2016/Goal-17/

Yeboah A (2011) Building and sustaining competitive advantage through Corporate Social Responsibility (CSR) and ethics in the telecommunication industry in ghana: a case study of MTN Ghana. Retrieved 27 Apr 2020, from https://tinyurl.com/YeboahBuilding 